\title{
Appropriate use of transdermal drug delivery systems
}

\author{
Peter J. Hughes, Maisha K. Freeman, Terri M. Wensel \\ McWhorter School of Pharmacy, Birmingham, AL USA \\ Correspondence: Peter J. Hughes. Address: 800 Lakeshore Drive, Birmingham, AL 35229 USA. Telephone: \\ 1-205-726-2519. Email: pjhughes@samford.edu.
}

Received: January 14, 2013

Accepted: February 4, $2013 \quad$ Online Published: April 11, 2013

DOI : 10.5430/jnep.v3n10p129

URL: http://dx.doi.org/10.5430/jnep.v3n10p129

\section{Abstract}

Background: Depending on the therapeutic target, transdermal drug delivery systems (TDDS) are designed to provide a continuous supply of drug through the skin to allow for local or systemic drug effects. The purpose of this descriptive review is to introduce practical theories behind TDDS for nurses. Additionally, the authors will compare and contrast different transdermal patch delivery systems and offer recommendations for appropriate use and administration of prescription products with an emphasis on nursing care.

Findings: A total of 18 individual or fixed combination active ingriedient prescription transdermal formulations are available for use in the United States. Appropriate use and disposal of TDDS are dictated by the active ingredient, patch type and several patient-specific characteristics such as age, gender, skin integrity and organ function.

Conclusions: Transdermal systems are convenient and therapeutically beneficial for select patient types. Appropriate application, disposal and monitoring techniques can optimize care for patients, caregivers and the general public.

\section{Key words}

Transdermal drug delivery, Skin absorption, Cutaneous drug transport

\section{I ntroduction}

Transdermal drug delivery systems (TDDS) are designed to administer drug products through the skin to provide systemic drug therapy ${ }^{[1,2]}$. Several advantages and disadvantages exist to this type of system. Transdermal drug delivery eliminates variables associated with decreased gastrointestinal absorption (e.g., changes in $\mathrm{pH}$, rate and extent of gastric emptying, transit time from drug administration to delivery to the site of action, drug delivery at a constant rate); therefore, transdermal administration is beneficial when a constant drug effect is desired. Drug concentrations are reached gradually and if adverse drug reactions are observed, the delivery system can be removed as soon as it is detected. As a result, adverse effects of drugs delivered in this manner may be reduced. Patient adherence may be increased as the transdermal route is associated with an ease in administration. Transdermal administration also avoids painful intravenous (IV) drug administration, IV site access, and syringe disposal. With TDDS, total drug dosage is reduced because first pass metabolism in the liver is bypassed, resulting in increased drug concentrations at the site of action ${ }^{[3]}$. In addition, the number of medications to be taken by elderly patients who are receiving many concomitant drugs may be reduced. Transdermal drug delivery may also be advantageous for patients who have difficulty swallowing tablets or have decreased venous access ${ }^{[1,4]}$. 
Although several advantages exist to administering TDDS, disadvantages can include skin irritation as a result of substances used to adhere the patch to the skin. Patches may be associated with a reservoir effect (i.e., pooling of drug that may be associated with inappropriate drug release from TDDS) and as a result, adjusting drug dosages may be difficult. Administration of patches may result in a lag time associated with the delivery of the drug through the skin and delay in the onset of action of the drug product ${ }^{[2]}$. In the elderly, the rate and extent of absorption may be delayed due to normal physiologic changes resulting in reduced adhesive effectiveness and/or physiologic changes in the skin ${ }^{[2]}$. Patients who have cognitive decline may forget they are wearing a patch, may administer several patches at a time, and experience additional adverse reactions ${ }^{[1]}$. In addition, several other factors (e.g., differences in patch designs, dosage or strength units, and abbreviations indicative of the patch's delivery system, administration frequency, and administration site) may confer additional confusion on the appropriate administration steps to use for the patch products ${ }^{[5]}$. Misuse of some TDDS have been reported in the literature and has been associated with increased morbidity and mortality ${ }^{[6]}$.

The purpose of this descriptive review is to provide the advantages and disadvantages of TDDS. Additionally, the authors will compare and contrast different transdermal patch delivery systems and offer recommendations for appropriate use and administration of prescription transdermal products with an emphasis on nursing care.

\section{Types of TDDS}

The ideal transdermal system allows the prescriber to optimize dosing to patient needs while supplying the desired drug and dose in a discreet manner. Yet, sometimes these objectives cannot be attained with fixed dose TDDS because this dosage form cannot be given in partial doses, unlike tablets or oral liquid formulations which can be dosed with more precision. Other factors that should be taken into consideration are the inter-individual or inter-site variability involving skin thickness or stratum corneum (SC) composition (i.e., dermatological disease, anatomical patch placement etc.) ${ }^{[7]}$. Additional factors that can contribute to variability with respect to transdermal drug absorption secondary to patch application include: dermal blood flow, chemicals in the skin that may accelerate drug metabolism, or use of irritating or abrasive cosmetic cleansers that could accelerate drug penetration through the $\mathrm{SC}^{[7]}$.

Reservoir (membrane-controlled) and matrix (monolithic) patch designs currently dominate the transdermal market. Fundamentally, reservoir systems have two essential elements: a drug reservoir (pocket for drug) and a semi-permeable membrane that allows for a constant, controlled release of active drug to the surface of skin (see Figure 1). The drug in the reservoir can be present in suspension, solution, gel, or a solid polymer matrix state. Reservoir TDDS should not be cut, as altering the integrity of the system could create a dose-dumping effect that can lead to drug toxicity (including death) or inadvertent drug exposure to others ${ }^{[8,9]}$.

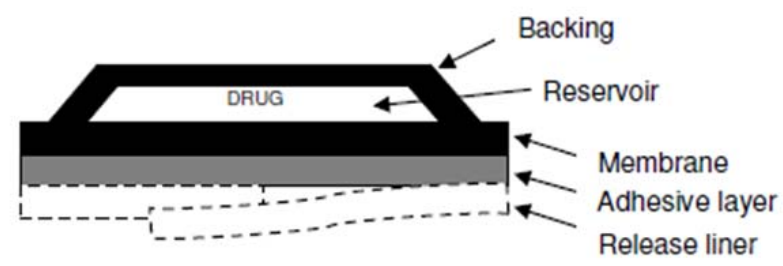

Figure 1. Diagram of reservoir TDDS

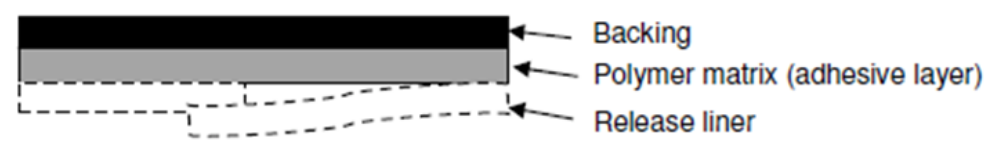

Figure 2. Diagram of matrix TDDS

Matrix (monolithic) systems contain a similar distribution of drug throughout the patch and exist in several forms including simple matrix systems, drug-in-adhesive system, and multilayer matrix systems ${ }^{[1]}$. All matrix TDDS 
incorporate active drug in a polymer matrix that regulates drug release via diffusion (i.e., drug concentrations moving from high concentrations to low concentrations) compared to reservoir systems which contain a rate-controlling membrane that is responsible for controlled release of transdermal formulations ${ }^{[1,5,10,11]}$. Simple matrix systems consist of a single polymer layer in which the active drug is contained. Drug-in-adhesive systems contain an adhesive layer that directly interfaces with the skin that contains the active drug. Drug-in-adhesive systems are typically thin and pliable which may improve patient adherence. Multilayer matrix systems are available, that contain different layers of polymer matrix with corresponding concentrations of drug, thus creating a sequential concentration gradient that facilitates diffusion from the patch to the skin. All matrix systems have an adhesive layer (containing drug) that is directly applied to the skin and the SC acts as a rate-controlling membrane (see Figure 2). Additionally, with matrix systems, the amount of drug delivered to dermal tissues has a direct relationship with the area of skin contact. Although, cutting of certain OTC and prescription matrix patches is acceptable and advantageous, in some cases this practice can alter the effectiveness of adhesion of certain patches (see Table 1) ${ }^{[5]}$. Product package inserts or another reliable, updated, drug information resource should be consulted before cutting or modifying any TDDS.

Table 1. Prescription transdermal patch products (Alphabetical by active ingredient)

\begin{tabular}{|c|c|c|c|c|c|c|}
\hline Generic Name & $\begin{array}{l}\text { Brand } \\
\text { Name }\end{array}$ & MFG & $\begin{array}{l}\text { Delivery } \\
\text { System }\end{array}$ & Application Instructions & $\begin{array}{l}\text { Dose Adjustment } \\
\text { for Age }\end{array}$ & $\begin{array}{l}\text { Dose Adjustment } \\
\text { for Renal / Hepatic } \\
\text { Impairment }\end{array}$ \\
\hline Buprenorphine $^{[32]}$ & Butrans & Purdue & Matrix & $\begin{array}{l}\text { Apply buprenorphine TDDS to the upper outer } \\
\text { arm, upper chest, upper back or the side of the } \\
\text { chest. } \\
\text { Rotate buprenorphine TDDS among the } 8 \\
\text { described skin sites. After removal, wait a } \\
\text { minimum of } 21 \text { days before reapplying to the } \\
\text { same skin site. } \\
\text { Apply buprenorphine TDDS to a hairless or } \\
\text { nearly hairless skin site. If none are available, the } \\
\text { hair at the site should be clipped, not shaven. }\end{array}$ & None & None \\
\hline Clonidine ${ }^{[33]}$ & $\begin{array}{l}\text { Catapres- } \\
\text { TTS }\end{array}$ & $\begin{array}{l}\text { Boehringer } \\
\text { Ingelheim }\end{array}$ & Reservoir & $\begin{array}{l}\text { Apply to hairless area of upper, outer arm or } \\
\text { chest. } \\
\text { Change patch every } 7 \text { days. } \\
\text { Rotate application site weekly. } \\
\text { May use the adhesive cover if the patch becomes } \\
\text { loose. }\end{array}$ & None & $\begin{array}{l}\text { No specific } \\
\text { recommendations; } \\
\text { monitor use if } \\
\text { impaired. }\end{array}$ \\
\hline Diclofenac $^{[34]}$ & Flector & King & Matrix & $\begin{array}{l}\text { Apply } 1 \text { patch to the most painful area twice a } \\
\text { day. } \\
\text { Do not apply to damaged skin. } \\
\text { Do not wear when bathing or showering. } \\
\text { Edges of patch may be secured with tape or } \\
\text { patient can secure to site of application with a } \\
\text { breathable mesh or joint sleeve that allows for } \\
\text { free flow of air. }\end{array}$ & None & $\begin{array}{l}\text { Use caution if } \\
\text { renally impaired. } \\
\text { Use with caution in } \\
\text { hepatically impaired } \\
\text { and discontinue } \\
\text { therapy if liver } \\
\text { function tests are } \\
\text { elevated. }\end{array}$ \\
\hline $\begin{array}{l}\text { Estradiol / } \\
\text { Norelgestromin }^{[35]}\end{array}$ & Ortho Evra & $\begin{array}{l}\text { Ortho } \\
\text { McNeil }\end{array}$ & Matrix & $\begin{array}{l}\text { Apply a new patch weekly on the same day of the } \\
\text { week. } \\
\text { Apply patch to a clean, dry, intact area of skin on } \\
\text { the buttock, abdomen, upper outer arm, or upper } \\
\text { torso. } \\
\text { Press firmly for } 10 \text { seconds to ensure adhesion } \\
\text { Week } 4 \text { is patch free. } \\
\text { Wear only } 1 \text { patch at a time. }\end{array}$ & $\begin{array}{l}\text { Not indicated for } \\
\text { patients }>65 \text { years } \\
\text { of age. }\end{array}$ & $\begin{array}{l}\text { May be poorly } \\
\text { metabolized in } \\
\text { patients with hepatic } \\
\text { impairment. }\end{array}$ \\
\hline $\begin{array}{l}\text { Estradiol / } \\
\text { Norethin- } \\
\text { drone }^{[36,37]}\end{array}$ & $\begin{array}{l}\text { CombiPatch, } \\
\text { Climara Pro }\end{array}$ & $\begin{array}{l}\text { Novartis; } \\
\text { Bayer } \\
\text { Healthcare }\end{array}$ & Matrix & $\begin{array}{l}\text { CombiPatch } \\
\text { Apply patch twice weekly. } \\
\text { Apply to a clean, dry and smooth area of the } \\
\text { lower abdomen. } \\
\text { Press firmly for } 10 \text { seconds to ensure adhesion. } \\
\text { Wear only } 1 \text { patch at a time. } \\
\text { Climara Pro. } \\
\text { Place on a smooth, dry and clean area of the lower } \\
\text { abdomen away from breasts. } \\
\text { Press firmly for } 10 \text { seconds to ensure adhesion. } \\
\text { Wear only } 1 \text { patch at a time. }\end{array}$ & None & $\begin{array}{l}\text { Contraindicated in } \\
\text { patients with liver } \\
\text { dysfunction or } \\
\text { disease. }\end{array}$ \\
\hline
\end{tabular}


Table 1. (continued)

\begin{tabular}{|c|c|c|c|c|c|c|}
\hline Generic Name & $\begin{array}{l}\text { Brand } \\
\text { Name }\end{array}$ & MFG & $\begin{array}{l}\text { Delivery } \\
\text { System }\end{array}$ & Application Instructions & $\begin{array}{l}\text { Dose } \\
\text { Adjustment for } \\
\text { Age }\end{array}$ & $\begin{array}{l}\text { Dose Adjustment } \\
\text { for Renal / Hepatic } \\
\text { Impairment }\end{array}$ \\
\hline Estradiol $^{[38-42]}$ & $\begin{array}{l}\text { Alora, } \\
\text { Vivelle-Dot, } \\
\text { Climara, } \\
\text { Menostar, } \\
\text { Estraderm }\end{array}$ & $\begin{array}{l}\text { Watson } \\
\text { Labs; } \\
\text { Bayer } \\
\text { Healthcare } \\
\text { Novartis }\end{array}$ & $\begin{array}{l}\text { Matrix } \\
\text { Reservoir }\end{array}$ & $\begin{array}{l}\text { Alora, Vivelle-Dot, Estraderm } \\
\text { Administer twice weekly to a clean, dry area. } \\
\text { Lower abdomen, upper buttocks or outer hip may be } \\
\text { used; avoid breast area. } \\
\text { Press patch firmly with palm for } 10 \text { seconds to } \\
\text { ensure adhesion. } \\
\text { Climara, Menostar. } \\
\text { Apply once weekly. } \\
\text { Apply to a clean, dry area on the lower abdomen or } \\
\text { upper buttock; avoid breast area. } \\
\text { Press firmly for } 10 \text { seconds to ensure adhesion. } \\
\text { Do not apply more than } 1 \text { patch at a time. }\end{array}$ & None & $\begin{array}{l}\text { Lower doses } \\
\text { warranted in those } \\
\text { with end stage renal } \\
\text { disease. } \\
\text { Contraindicated in } \\
\text { patients with liver } \\
\text { dysfunction or } \\
\text { disease. }\end{array}$ \\
\hline Fentanyl $^{[29]}$ & Duragesic & $\begin{array}{l}\text { Ortho-Mc } \\
\text { Neil } \\
\text { Janssen }\end{array}$ & Matrix & $\begin{array}{l}\text { Do not use patches that have been damaged in any } \\
\text { way. } \\
\text { Patches may be worn for } 72 \text { hours; the next patch } \\
\text { should be applied to a different area. } \\
\text { Patches should be applied to the chest, back, flank, } \\
\text { or upper arm. } \\
\text { Press the patch firmly in place for } 30 \text { seconds to } \\
\text { ensure adhesion. } \\
\text { First aid tape may be used around the edges of the } \\
\text { patch if there are adhesion problems. }\end{array}$ & $\begin{array}{l}\text { Use caution as } \\
\text { metabolism and } \\
\text { elimination may } \\
\text { be altered. }\end{array}$ & $\begin{array}{l}\text { Insufficient } \\
\text { information; Use } \\
\text { caution if the patient } \\
\text { has impairment. } \\
\text { Avoid use with } \\
\text { severe renal or } \\
\text { hepatic dysfunction. }\end{array}$ \\
\hline Granisetron $^{[43]}$ & Sancuso & ProStrakan & Matrix & $\begin{array}{l}\text { Apply to clean, dry, intact skin. } \\
\text { Apply to the upper arm. } \\
\text { Patch should be applied a minimum of } 24 \text { hours and } \\
\text { a maximum of } 48 \text { hours prior to chemotherapy. } \\
\text { Patch should be removed a minimum of } 24 \text { hours } \\
\text { after chemotherapy. } \\
\text { Patch may remain in place up to } 7 \text { days depending } \\
\text { on the chemotherapy regimen. } \\
\text { Medical tape can be used to keep patch in place; do } \\
\text { not completely cover patch with tape. }\end{array}$ & $\begin{array}{l}\text { Insufficient } \\
\text { data; use } \\
\text { caution. }\end{array}$ & $\begin{array}{l}\text { Based upon studies } \\
\text { with intravenous } \\
\text { granisetron, no renal } \\
\text { or hepatic } \\
\text { adjustments needed. }\end{array}$ \\
\hline $\begin{array}{l}\text { Lidocaine/ } \\
\text { tetracaine }{ }^{[44]}\end{array}$ & Synera & ZARS & $\begin{array}{l}\text { Reservoir } \\
\text { with } \\
\text { heating } \\
\text { system }\end{array}$ & Apply to intact skin 30 minutes prior to procedure. & $\begin{array}{l}\text { None; elderly } \\
\text { patients may be } \\
\text { more sensitive } \\
\text { to effects. }\end{array}$ & $\begin{array}{l}\text { No specific data. } \\
\text { Half-life may be } \\
\text { prolonged in } \\
\text { patients with hepatic } \\
\text { impairment. Patients } \\
\text { with severe hepatic } \\
\text { impairment may } \\
\text { poorly metabolize } \\
\text { lidocaine and be at } \\
\text { an increased risk of } \\
\text { toxicity. }\end{array}$ \\
\hline Lidocaine $^{[45]}$ & Lidoderm & Endo & Matrix & $\begin{array}{l}\text { Apply to intact skin over the most painful area. } \\
\text { Up to } 3 \text { patches may be applied at } 1 \text { time in a } 12 \\
\text { hour period. } \\
\text { Important to adhere to a } 12 \text { hour application period } \\
\text { and a } 12 \text { hour application-free period per day. } \\
\text { May cut patch to cover size of treatment area. }\end{array}$ & None & $\begin{array}{l}\text { Patients with severe } \\
\text { hepatic impairment } \\
\text { may not metabolize } \\
\text { lidocaine normally } \\
\text { and are at increased } \\
\text { risk of toxicity. }\end{array}$ \\
\hline Nitroglycerin ${ }^{[47,48]}$ & $\begin{array}{l}\text { Nitro-Dur, } \\
\text { Minitran }\end{array}$ & $\begin{array}{l}\text { Merck, } \\
\text { Medicis, } \\
\text { Alvogen, } \\
\text { Mylan, } \\
\text { Major, } \\
\text { Hercon, } \\
\text { Kremers } \\
\text { Urban }\end{array}$ & Reservoir & $\begin{array}{l}\text { Apply patches daily for a } 12 \text { to } 14 \text { hour time } \\
\text { frame. } \\
\text { Daily patch free time should be } 10-12 \text { hours. }\end{array}$ & $\begin{array}{l}\text { Insufficient } \\
\text { information; } \\
\text { Elderly patient } \\
\text { may be more } \\
\text { sensitive to } \\
\text { effects. Use lower } \\
\text { end of dosing } \\
\text { range. }\end{array}$ & Use caution \\
\hline
\end{tabular}


Table 1. (continued)

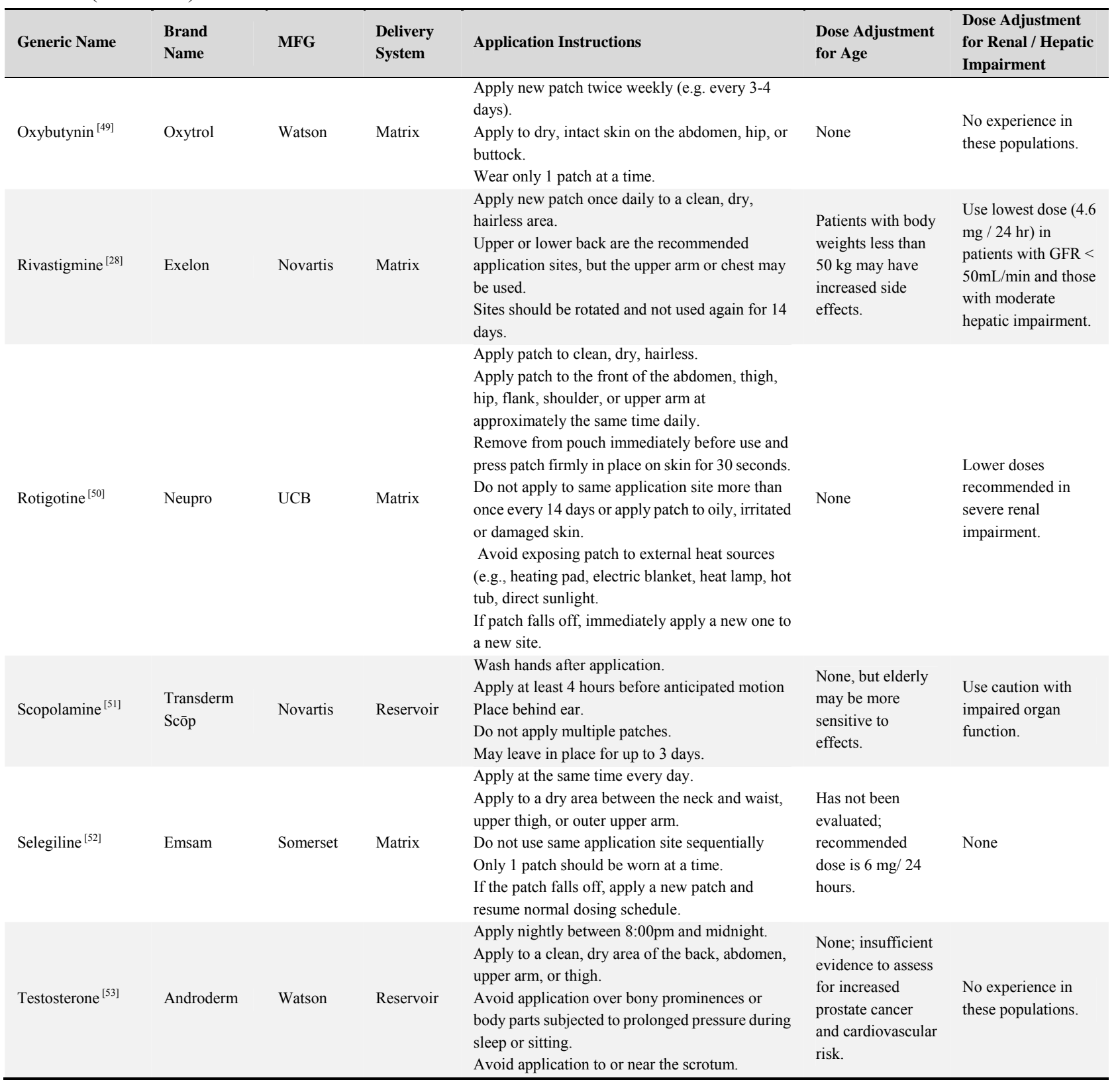

Transderm Scop was the first transdermal system approved by the Food and Drug Administration in 1979 for the relief of the symptoms of motion sickness, nausea, and vomiting ${ }^{[5]}$. Since then, TDDS have gone through several changes. Currently, there are three generations of TDDS. The majority of the transdermal drug products approved for clinical use are considered first-generation products. These products are characterized by their low molecular weight (i.e., smaller size), lipophilic nature (i.e., fatty disposition), and efficacy at low doses. In addition, they are able to deliver drug products to the $\mathrm{SC}$ with subsequent diffusion to the site of action ${ }^{[12]}$.

Second generation TDDS have resulted in improved small molecular delivery; however, very little impact has been made for the delivery of macromolecules (larger drug products). Some of the developments that have been made with this generation of agents include conventional chemical enhancers (chemical excipients used to increase skin permeation), iontophoresis (application of a low voltage current to increase drug penetration), and non cavitational ultrasounds (i.e., instituting ultrasonic heating techniques to enhance drug penetration) ${ }^{[12]}$. 
Third-generation TDDS target their effects to the SC allowing for a more intense disruption of the SC barrier and enhancing transdermal drug delivery. Techniques that have been used include chemical enhancers (introduction of chemical excipients that are associated with less skin irritation than second generation agents), electroporation (use of short, high-voltage pulses to disrupt cell membranes and allow for increased drug permeability to the skin), cavitational ultrasound (use of low frequency ultrasound that enhances drug penetration), microneedles (piercing the SC to delivery medications in a minimally invasive manner), thermal ablation (allows for selective heating of the skin surface to generate perforations in the SC to enhance drug penetration), and microdermabrasion (removing skin to enhance drug penetration) ${ }^{[12]}$.

While TDDS differ in method of delivery, they do have three functional features in common. First, the occlusive backing film prevents inadvertent drug loss or drug exposure to persons other than the patient and also improves drug penetration. If possible, the backing film should be constructed in such a way that is it clearly visible to others. Common components of backing films include clear or colored aluminum films, polyethylenes, polyurethanes, or polyesters ${ }^{[13]}$. Second, both patch types contain an adhesive layer. In matrix patches the adhesive layer contains the drug matrix, while with reservoir systems, the adhesive layer simply serves to attach and maintain constant and consistent contact between the transdermal system and skin. With reservoir systems, adhesive layers do not contain active drug. Finally, the protective release liner preserves patch integrity prior to application and prevents inadvertent exposure to drug to the fingers of the person applying the patch. The release liner is removed and discarded prior to patch application.

\section{Safety of transdermal drug delivery systems}

Transdermal drug delivery systems have an improved safety profile as this delivery system can be absorbed adequately in patients who do not have a functional gastrointestinal tract. In addition, transdermal formulations typically have a favorable drug concentration profile as the factors that limit gastrointestinal absorption (e.g., changes in $\mathrm{pH}$, rate and extent of gastric emptying, transit times, presence/interaction with food, intestinal motilities) are avoided ${ }^{[1]}$. Delayed absorption prevents peaks and valleys associated with variations in drug concentrations. Lack of venous access, reduction in infection risk, improved compliance and potential for use in patients who are unable to swallow are also indicative of an improved safety profile associated with these delivery systems ${ }^{[1,14]}$. Drug deactivation typically occurs with orally administration drugs via first-pass metabolism and interaction with liver and digestive enzymes. TDDS avoid first-pass metabolism, the process by which the liver metabolizes drug products before it passes into systemic circulation ${ }^{[1,14]}$. In this context, TDDS may reduce drug-drug interactions associated with concomitant medications that are metabolized in the liver ${ }^{[14]}$.

Adverse effects secondary to TDDS use can range from dermatitis to death from secondary causes.

Irritant reactions should be distinguished from allergic reactions. Irritant reactions are characterized by a peak effect at the time of removal, no reaction at former sites, localization to site of application, and development of vesicles with no infiltration. Conversely, allergic reactions increase in severity after removal. Furthermore, reactions at sites of previous application are possible, extension of reaction beyond the site of administration may occur, and vesicles and infiltration are more likely with allergic reactions compared to irritant reactions ${ }^{[14]}$. Contact sensitivity should be prevented by following the manufacturer's guidelines regarding the site of application: apply product to clean skin with a dry cloth, avoid soap and detergents; apply device to no irritated skin; apply product to a region that has the least amount of hair possible; clip hair around area; and rotate application sites ${ }^{[14]}$.

Some TDDS products may predispose patients to burns when receiving MRI scans. A transdermal system formulated with an aluminum backing could possibly injure a patient if worn during MRI procedures. Use of these patches during MRI procedures may cause a concentration of electrical currents to be directed at the application site thereby resulting in excessive heating and tissue damage ${ }^{[15]}$. The FDA has released several reports warning of the increased risk of excessive 
heating and burns associated with the use of MRIs in patients wearing patches and has included an updated list of prescription and OTC drugs that should be avoided during MRI procedures (e.g., clonidine, rotigotine, lidocaine/ epinephrine; lidocaine/tetracaine; scopolamine; nicotine; testosterone; fentanyl; and methyl salicylate/menthol) ${ }^{[16]}$.

The same safety measures should be taken with patch formulations that are taken with other pharmaceutical dosage forms. Numerous case reports exist detailing the deleterious results of transdermal system misuse or inadvertent patch application. Potentially toxic medications such as fentanyl (Duragesic) and clonidine (Catapres TTS) pose the greatest threat if misused or abused. It is important for patients to regularly monitor patch placement if using patches that are applied for extended periods of time (i.e., greater than 24 hours) as patches have been reported to move, fall off, or re-attach to other persons with whom the patient has had close contact ${ }^{[17]}$. In patients with dementia or cognitive impairment a beneficial approach to monitoring of patch placement and dosing could be marking the date of application on a piece of medical tape that is applied in close proximity to the applied patch to serve as a reminder of date of patch placement. While some advocate the practice of writing directly on the backing of the patch, it is unknown whether ink could cross this barrier and interact with active drug. Furthermore, the possibility of a sharp writing instrument (i.e., pen) puncturing the backing liner exists ${ }^{[18]}$. This method may reduce adverse drug reactions, including overdoses.

News reports and the literature detail the deaths of individuals and risk of death involved with prescription drug diversion of narcotic patches (Duragesic and generic equivalents). Fatalities are commonly due to cutting patches in half, chewing and parking them in the buccal cavity (area between cheek and gum) or smoking patches for recreational purposes ${ }^{[19-23]}$. Furthermore, faulty patches that inadvertently leak reservoir contents have also been reported and have been subject to nationwide recall ${ }^{[24]}$. Of note, accidental and intentional overdose situations precipitated product reformulation of fentanyl TDDS to a matrix system in 2009 to decrease inadvertent exposure and intentional abuse. In their most recently published annual report, the American Association of Poison Control Centers reports that fentanyl transdermal system is a common drug product involved in single substance pharmacological exposures. Of the 167 exposures reported to poison centers nationwide in 2010, 125 occurred in adults $\geqslant 20$ years of age, 104 of which were intentional acts of exposure. Furthermore, of the 167 registered exposures, 116 were referred to a healthcare facility for treatment, resulting in 50,18 and 2 moderate illnesses, major illnesses and fatalities, respectively ${ }^{[25]}$.

Additionally, several reports of intentional or unintentional toxicity have been documented secondary to inappropriate patch disposal ${ }^{[26,27]}$. The Institute for Safe Medication Practices recommends that a risk management program should be outlined that requires the disposal of patches in biohazard containers that cannot be opened; transdermal fentanyl patches should have child-protective packaging; improved methods of documentation should be developed in hospital settings to reduce the number of patches applied to patients at one time; and development of a dosing calendar for patients to document the location and time of application and removal of patches at home is encouraged ${ }^{[26,27]}$. Different manufacturers of transdermal patch products have provided instructions on how to properly dispose of these products. For instance, Novartis, the manufacturer of rivastigmine transdermal patch (Exelon) recommends that the used patch should be folded in half with the adhesive sides on the inside of the fold. The used patch should be returned to its original pouch and discarded safely out of the reach and sight of children and pets as there may be undelivered medicine residing in the patch $^{[28]}$. The manufacturer of the fentanyl TDDS suggests that upon removal, the patch should be folded in a manner that the adhesive sides adhere to itself and immediately flushed down the toilet ${ }^{[29]}$.

Heat sources (e.g., hot water bottle, electrical heating devices) should not be applied to TDDS, as heat may increase the amount of drug delivery to the site of application ${ }^{[1]}$. Researchers evaluated the effect of heat and compromised skin on the transdermal delivery of fentanyl from matrix and reservoir systems ${ }^{[30]}$. Using a model of human cadaver skin samples, Proddutrui et al discovered that when the temperature was increased from $32^{\circ} \mathrm{C}\left(89.6^{\circ} \mathrm{F}\right)$ to $40^{\circ} \mathrm{C}\left(104^{\circ} \mathrm{F}\right)$, drug permeation was increased by two fold over the first 24 hours. At 72 hours, the total drug permeation was significantly higher in the reservoir fentanyl TDDS compared with the matrix system. Due to differences in release characteristics of transdermal 
formulations, these products should be used as directed to prevent inappropriate drug delivery, especially for highly potent drugs ${ }^{[30]}$.

Although TDDS appear to be relatively safe, the majority of adverse effects result from inappropriate administration of the product and monitoring after transdermal system placement. Lack of patch adhesion can pay a role in the safety and efficacy of the products ${ }^{[31]}$. Some patches can be re-secured with medical tape around the edges or with the application of a clear plastic bandage (e.g., Tegaderm) (See Table 1). However, with certain patches, manufacturers recommend discarding the original patch and applying a new patch in the event of a patch falling off. It is important to consult the most recent product package labeling or a reliable drug information resource to gather product-specific recommendations. Reports of poor patch adhesion resulting in adverse events, loss of efficacy, increased drug costs, and lack of safety are abundant. Therefore, prescribers are encouraged to educate patients on patch use.

Table 2. Transdermal drug delivery system safety pearls

- Irritant reactions with TDDSs are common; distinguish these reactions from allergic reactions

- $\quad$ Prevent contact sensitivity from TDDS by utilizing these safe and common methods

o Apply TDDS to clean skin

o Avoid use of soaps, detergents and abrasives at applied areas

o Apply TDDS to areas approved by package labeling that have the least amount of hair

o If hair removal is necessary, trim the hair with scissors; do not shave off with a razor

o Rotate application sites regularly

- TDDS with aluminum backing films should NEVER be attached to patient undergoing an MRI

- $\quad$ Never cut TDDS unless the package labeling states otherwise

- Although convenient and save, patients receiving TDDS should still be monitored for adverse events

- Dispose of TDDS in accordance with product package labeling

- Do not heat body parts that have TDDS placed on them as this can lead to accelerated drug release and patient harm

- Do not cover TDDS with an occlusive dressing unless the labeling states otherwise

\section{Conclusions}

Transdermal drug delivery systems represent a beneficial innovation for drug delivery, particularly in patients who cannot swallow or remember to take their medications. Furthermore, TDDS can be beneficial due to the avoidance of metabolism by the liver, more sustained drug concentrations, and ease of administration. Clinicians and other allied health professionals should understand the appropriate administration techniques for transdermal systems to ensure optimal patient outcomes and to ensure the safety of all who encounter patients who use TDDS.

\section{References}

[1] Kaestli LZ, Wasilewski-Rasca A, Bonnabry P, Vogt-Ferrier N. Use of transdermal drug formulations in the elderly. Drugs Aging. 2008; 25(4): 269-280. PMid:18361538 http://dx.doi.org/10.2165/00002512-200825040-00001

[2] Tanner T, Marks R. Delivering drugs by the transdermal route: review and comment. Skin Res Techn. 2008; 14: $249-260$. PMid:19159369 http://dx.doi.org/10.1111/j.1600-0846.2008.00316.x

[3] Callaghan TM, Wilhelm KP. A review of ageing and an examination of clinical methods in the assessment of ageing skin. Part 2: clinical perspective s and clinical methods in evaluation of ageing skin. In J Cos Science. 2008; 30: 323-332.

[4] Ranade VV. Drug delivery systems. Transdermal drug delivery. J Clin Pharmacol. 1991; 31: 401-418. PMid:2050824 http://dx.doi.org/10.1002/j.1552-4604.1991.tb01895.x

[5] Ball AM, Smith KM. Optimizing transdermal drug therapy. Am J Health-Syst Pharm. 2008; 65: 1337-1346. PMid:18593680 http://dx.doi.org/10.2146/ajhp070554

[6] Paparella S. Transdermal patches: an unseen risk for harm. J Emerg Nursing. 2005; 31(3): 278-281. PMid:15983583

http://dx.doi.org/10.1016/j.jen.2005.01.010 
[7] Thomas BJ, Finnin BC. The transdermal revolution. Drug Discov Today. 2004; 9(16): 697-703. http://dx.doi.org/10.1016/S1359-6446(04)03180-0

[8] Lee M, Phillips J. Transdermal patches: high risk for error? Drug Topics. 2002; 146(7): 54-55.

[9] Anderson DT, Muto JJ. Duragesic transdermal patch: postpartum tissue distribution of fentanyl in 25 cases. J Anal Toxicol. 2000; 24(7): 627-634. PMid:11043670

[10] Farahmand S, Maibach HI. Transdermal drug pharmacokinetics in man: interindividual variability and partial prediction. Int $\mathrm{J}$ Pharm. 2009; 367(1-2): 1-15. PMid:19100821 http://dx.doi.org/10.1016/j.ijpharm.2008.11.020

[11] Schulmeister L. Transdermal drug patches: medicine with muscle. Nursing .2005; 35(1): 48-52. PMid:15622207

[12] Prausnitz MR, Langer R. Transdermal drug delivery. Nat Biotechnol. 2008; 26(11): 1261-1268. PMid:18997767 http://dx.doi.org/10.1038/nbt.1504

[13] Desai A. Topical and transdermal drug delivery systems. In: Desai A, Lee M, eds. Gibaldi's Drug Delivery Systems in Pharmaceutical Care. Bethesda, MD: American Society of Health-System Pharmacists. 2007: 50-54.

[14] Murphy M, Carmichael A. Transdermal drug delivery systems and skin sensitivity reactions: incidence and management. Am J Clin Dermatol. 2000; 1(6): 361-368. PMid:11702612 http://dx.doi.org/10.2165/00128071-200001060-00004

[15] Burns in MRI patients wearing transdermal patches. Available from: http:/www.ismp.org/Newsletters/acutecare/articles/20040408.asp (8 April 2004, Accessed 5 November 2012).

[16] Public Health Advisory: Risk of burns during MRI scans from transdermal drug patches with metallic backings. Available from: http://www.fda.gov/Drugs/DrugSafety/PostmarketDrugSafetyInformationforPatientsandProviders/DrugSafetyInformationforHea thcareProfessionals/PublicHealthAdvisories/ucm111313.htm (9 March 2009, Accessed 5 November 2012).

[17] Behrman A, Goertemoeller S. A sticky situation: toxicity of clonidine and fentanyl transdermal patches in pediatrics. J Emerg Nurs. 2007; 33(3): 290-293. PMid:17517283 http://dx.doi.org/10.1016/j.jen.2007.02.004

[18] Durand C, Alhammad A, Willett KC. Practical considerations for optimal drug delivery. Am J Health Syst Pharm. 2012; 62(2): 116-124. PMid:22215357 http://dx.doi.org/10.2146/ajhp110158

[19] Brookens J. Overdose becomes homicide. Fairmont Sentinel Online. Fairmont, Minnesota. http://www.fairmontsentinel.com/page/content.detail/id/516791.html (8 March 2011, Accessed November 5, 2012).

[20] Adams, K. Search for answers in fentanyl death raises more questions. The Virginian Pilot Online. Hampton, Virginia. Available from: http:/hamptonroads.com/2010/05/search-answers-fentanyl-death-raises-more-questions (18 May 2010, Accessed 24 February 2012).

[21] Yearasi AB, Butts JD, Butts JD. Disposal of used fentanyl patches. Am J Health-Syst Pharm. 1997; 54: 85-86.

[22] Teske J, Weller J, Larsch K, Troger HD, Karst M. Fatal outcome in a child after ingestion f a transdermal fentanyl patch. Int J Legal Med. 2007; 121: 147-151. PMid:17115172 http://dx.doi.org/10.1007/s00414-006-0137-3

[23] Arvanitis ML, Satonik RC. Transdermal fentanyl abuse and misuse. Am J Emer Med. 2002; 20(1): 58-59. PMid:11781919 http://dx.doi.org/10.1053/ajem.2002.29562

[24] Actavis Recalls Fentanyl Patches in the US as a Precaution. FDA web site. Available from: http://www.fda.gov/Safety/Recalls/ArchiveRecalls/2008/ucm112381.htm (17 February 2008, Accessed 5 November 2012).

[25] Bronstein AC, Spyker DA, Cantilena LR, Green JL, Rumack BH, Cart RC. 2010 Annual Report of the American Association of Poison Centers' National Poison Data System (NPDS): 28th Annual Report. Clin Toxicol. 2011; 49(10): 910-941. PMid:22165864 http://dx.doi.org/10.3109/15563650.2011.635149

[26] Proper disposal of fentanyl patches is critical to prevent accidental exposures. ISMP web site. Available from: http://www.ismp.org/nan/files/nan-20120425.pdf (25 April 2012, Accessed 5 November 2012).

[27] ISMP calls for more action to safeguard pain patches. ISMP web site. Available from: http://www.ismp.org/pressroom/PR20050818.pdf (18 August 2005, Accessed 9 December 2012).

[28] Exelon [Package Insert]. East Hanover, NJ: Novartis Pharmaceuticals Corp.; August 2012. Available from: http://www.pharma.us.novartis.com/product/pi/pdf/exelonpatch.pdf (Accessed 6 November 2012).

[29] Duragesic [package insert]. Titusville, NJ: Janssen Pharmaceuticals, Inc.: July 2012. Available from: http://www.duragesic.com/duragesic/shared/pi/duragesic.pdf (Accessed 6 November 2012).

[30] Prodduturi S, Sadrieh N, Wokovich AM, Doub WH, Westenberger BJ, Buhse L. Transdermal delivery of fentanyl from matrix and reservoir systems: effect of heat and compromised skin. J Pharm Sci. 2010; 99(5): 2357-2366.

[31] Wokovich AM, Prodduturi S, Doub WH, Hussain AS, Buhse LF. Transdermal drug delivery system (TDDS) adhesion as a critical safety, efficacy and quality attribute. Eur J Pharm Biopharm. 2006; 64(1): 1-8. PMid:16797171 http://dx.doi.org/10.1016/j.ejpb.2006.03.009

[32] Butrans [package insert]. Stamford, CT: Purdue Pharma L.P.: July 2012. Available from: http://app.purduepharma.com/xmlpublishing/pi.aspx?id=b (Accessed 6 November 2012). 
[33] Catapres [package insert]. Ridgefield, CT: Boehringer Ingelheim: May 2012. Available from: http://dailymed.nlm.nih.gov/dailymed/lookup.cfm?setid=fe0f5dcb-65dd-4d31-80d6-8b97eb040063 (Accessed 6 November 2012).

[34] Flector [package insert]. Bristol, TN: King Pharmaceuticals, Inc: August 2011. Available from: http://labeling.pfizer.com/ShowLabeling.aspx?id=829 (Accessed 6 November 2012).

[35] Ortho Evra [package insert]. Manati, PR: Janssen Ortho, LLC: August 2012. Available from: http://labeling.pfizer.com/ShowLabeling.aspx?id=829 (Accessed 6 November 2012).

[36] CombiPatch [package insert]. East Hanover, NJ: Novartis Pharmaceuticals Corp: May 2006. Available from: http://www.pharma.us.novartis.com/product/pi/pdf/combipatch.pdf (Accessed 6 November 2012).

[37] ClimaraPro [package insert]. Wayne, NJ: Bayer HealthCare Pharmaceuticals, Inc.: June 2009. Available from: http://dailymed.nlm.nih.gov/dailymed/lookup.cfm?setid=184d3092-7fc6-4375-816b-1ab06bb99cfd (Accessed 6 November 2012).

[38] Alora [package insert]. Corona, CA: Watson Pharmaceuticals, Inc: February 2012. Available from: http://dailymed.nlm.nih.gov/dailymed/lookup.cfm?setid=a0d4f0b8-5dcc-4ffe-9590-0203e869622f (Accessed 6 November 2012).

[39] Vivelle-Dot [package insert]. East Hanover, NJ: Novartis Pharmaceuticals Corp: February 2010. Available from: http://dailymed.nlm.nih.gov/dailymed/lookup.cfm?setid=e6f2e7ed-41a9-4a53-ac80-0cb1 fa2edcbf (Accessed 6 November 2012).

[40] Climara [package insert]. Wayne, NJ: Bayer HealthCare Pharmaceuticals: June 2009. Available from: http://dailymed.nlm.nih.gov/dailymed/lookup.cfm?setid=1e9702c4-f2d7-4ea8-b6e8-7dca31671864 Accessed 6 November 2012).

[41] Menostar [package insert]. Wayne, NJ: Bayer HealthCare Pharmaceuticals, Inc.: June 2009. Available from: http://dailymed.nlm.nih.gov/dailymed/lookup.cfm?setid=a78708cd-04d4-4221-a4e4-53680bbe2912 (Accessed 6 November 2012).

[42] Estraderm [package insert]. East Hanover, NJ: Novartis Pharmaceuticals Corp: March 2007. Available from: http://dailymed.nlm.nih.gov/dailymed/lookup.cfm?setid=83b78f99-df2e-46c5-b308-03bac56a8c8f (Accessed 6 November 2012).

[43] Sancuso [package insert]. Bedminster, NJ: ProStrakan Inc: September 2011. Available from: http://dailymed.nlm.nih.gov/dailymed/lookup.cfm?setid=ba44e7d8-0c71-4eb9-a951-3d91038293c5 (Accessed 6 November 2012).

[44] Synera [package insert]. ZARS Pharma, Inc: Ferndale, MI: March 2012. Available from: http://dailymed.nlm.nih.gov/dailymed/lookup.cfm?setid=b3eee508-8bf3-4bd3-9a71-47ee6ea87f95 (Accessed 6 November 2012).

[45] Lidoderm [package insert]. Chadds Ford, PA: Endo Pharmaceuticals Inc: March 2010. Available from: http://dailymed.nlm.nih.gov/dailymed/lookup.cfm?setid=flc40164-4626-4290-9012-c00e33420a33 (Accessed 6 November 2012).

[46] Daytrana [package insert]. Wayne, PA: Shire US Inc: August 2011. Available from: http://dailymed.nlm.nih.gov/dailymed/lookup.cfm?setid=12a36e92-cb00-48d5-8981-89d8cce8c4c6 (Accessed 6 November 2012).

[47] Nitro-Dur [package insert]. Whitehouse Station, NJ: Merck Sharp \& Dohme Corp.; May 2012. Available from: http://dailymed.nlm.nih.gov/dailymed/lookup.cfm?setid=5de5366c-0719-4a4c-9483-cd99b218ee78 (Accessed 6 November 2102).

[48] Minitran [package insert]. Bristol, TN: Graceway Pharmaceuticals, LLC; April 2007. Available from: http://dailymed.nlm.nih.gov/dailymed/lookup.cfm?setid=b17f29ca-517e-4d89-84f1-024d98fc5d77 (Accessed 6 November 2012).

[49] Oxytrol [package insert]. Corona, CA: Watson Pharmaceuticals, Inc: October 2012. Available from: http://dailymed.nlm.nih.gov/dailymed/lookup.cfm?setid=a162fd5b-b2ab-4d45-8861-71b60b92acb4 Accessed 6 November 2012).

[50] Neupro [package insert]. Smyrna, GA: UCB Pharmaceuticals, Inc: April 2012. Available from: http://dailymed.nlm.nih.gov/dailymed/lookup.cfm?setid=939e28c5-f3a9-42c0-9a2d-8d471d82a6e0 (Accessed 6 November 2012).

[51] Transderm Scop [package insert]. Summit, NJ: Novartis Consumer Health, Inc; September 2012. Available from: http://dailymed.nlm.nih.gov/dailymed/lookup.cfm?setid=4d705c57-fa98-46e0-97f3-38e1b0ada76b (Accessed 6 November 2012).

[52] Emsam [package insert]. Tampa, FL: Somerset Pharmaceuticals, Inc: August 2011. Available from: http://dailymed.nlm.nih.gov/dailymed/lookup.cfm?setid=b891bd9f-fdb8-4862-89c5-ecdd700398a3 (Accessed 6 November 2012).

[53] Androderm [package insert]. Corona, CA: Watson Pharmaceuticals, Inc: April 2012. Available from: http://dailymed.nlm.nih.gov/dailymed/lookup.cfm?setid=ac40e05b-6e67-4ff9-a0e8-2e897e71b282 (Accessed 6 November 2012). 